\title{
RACE DIVERSITY AND COMPLEXITY IN POPULATIONS OF THE SORGHUM ANTHRACNOSE FUNGUS Colletotrichum graminicola
}

\author{
CARLOS ROBERTO CASELA ${ }^{1}$, FREDOLINO GIACOMINI SANTOS ${ }^{1}$, ALEXANDRE DA SILVA \\ FERREIRA $^{1}$
}

\begin{abstract}
${ }^{1}$ Pesquisadores, Embrapa Milho e Sorgo. Caixa Postal 151, CEP. 35701-970 Sete Lagoas, MG. E-mail: casela@cnpms.embrapa.br
\end{abstract}

Revista Brasileira de Milho e Sorgo, v.3, n.1, p.30-37, 2004

\begin{abstract}
The phenotypic diversity of the sorghum anthracnose fungus Colletotrichum graminicola was analyzed through virulence on 10 sorghum lines. Isolates of the pathogen were obtained from three locations of severe anthracnose epidemics: Sete Lagoas (MG), Pelotas (RS), and Cravinhos (SP). Populations were compared through the Shannon diversity index and through a pathogenicity association coefficient (PAC) and a virulence association coefficient (VAC). Despite high values obtained, a large portion of information on the phenotypic diversity in all populations was lost due to deviation from the ideal frequency of 0.5 for virulence to each sorghum genotype. Six two-line and 11 three-line combinations were identified with low virulence association in the pathogen population. Lines CMSXS215B, CMSXS116, and CMSXS227R, present in all combinations with high PAC and low VAC, were identified as potential sources for stable and durable resistance to C. graminicola.
\end{abstract}

Key words: sorghum anthracnose, Colletotrichum graminicola, pathogen variability

\section{DIVERSIDADE E COMPLEXIDADE RACIAL EM POPULAÇÕES DE Colletotrichum graminicola, AGENTE CAUSAL DA ANTRACNOSE DO SORGO}

RESUMO - A diversidade fenotípica de Colletotrichum graminicola, agente causal da antracnose em sorgo, foi analisada através da virulência em dez linhagens de sorgo. Os isolados do patógeno foram obtidos de três locais de ocorrência de severas epidemias da doença: Sete Lagoas (MG), Cravinhos (SP) e Pelotas (RS). Populações foram analisadas através do índice de diversidade de Shannon e através de coeficientes de associação de patogenicidade (PAC) e do coeficiente de associação de virulência (VAC). Apesar dos altos valores obtidos, grande parte da informação sobre diversidade foi perdida devido a desvios na frequência de 0,5 de virulência a cada genótipo de sorgo. Foram identificadas seis combinações duas a duas e 11 combinações triplas com baixos coeficientes de associação de virulência na população. As linhagens CMSXS215B, CMSXS116 e CMSXS227R, presentes em todas as combinações com alto PAC e baixo VAC, foram identificadas como fontes potenciais de resistência durável e estável a C. graminicola.

Palavras-chave: antracnose do sorgo, Colletotrichum graminicola, variabilidade patogênica.

Sorghum anthracnose has been one of the major threats to sorghum production in Brazil. The disease reduces yield of sorghum crops and is particularly damaging under warm and humid 
weather (Ali \& Warren, 1987). Colletotrichum graminicola is a highly variable pathogen and infects all the above ground parts of the plant, but the leaf phase of the disease is more important for its capacity to reduce yield of sorghum grains and fodder by $50 \%$ or more, depending on the severity of the epidemics (Cardwell et al., 1989; Harris \& Johnson, 1964; Ferreira \& Warren, 1982). Pathotypes of $C$. graminicola have been characterized in Brazil based on the differential reaction of a host set of nine sorghum cultivars (Casela \& Ferreira, 1987).

Dilatory resistance, characterized by a slow rate of disease development, suffices for the control of sorghum anthracnose in some areas of the country, but a specific host-pathogen interaction is known for some sorghum genotypes and pathogen isolates, which indicates that at least a portion of the dilatory resistance of sorghum to C. graminicola is race specific, and, consequently, could be of low durability (Guimarães et al., 1998). Other alternative strategies have been explored to obtain stable and durable resistance, such as the identification of male-sterile (A) and restorer $(\mathrm{R})$ lines for which there is no virulence association in the pathogen population. Disease nurseries with elite lines are planted on hot spot areas of the disease and evaluated for resistance. Single spore isolates are obtained from samples collected from each field and inoculated in the elite lines in the greenhouse to identify combinations of $\mathrm{A}$ and $\mathrm{R}$ lines with non-associated virulences (Casela et al., 1998). New combinations are selected based on a pathogenicity association coefficient (PAC) and a virulence association coefficient (VAC), according to Browder \& Eversmeyer (1977). Based on these coefficients, desirable combinations for disease control area characterized by a high PAC and a low VAC, so that the greatest portion of the population will be avirulent on both $\mathrm{A}$ and $\mathrm{R}$ lines.

The objective of this work was to evaluate the pathotype diversity and complexity of three populations of $C$. graminicola, and to identity new combinations of sorghum genotypes potentially useful as sources of durable and stable resistance to this pathogen.

\section{Material and Methods}

Isolates of $C$. graminicola were obtained from three locations: Sete Lagoas (MG), Cravinhos (SP), and Pelotas (RS) in the years 1999 and 2000. Samples from Pelotas and Sete Lagoas were collected from host populations formed by a mixture of 10 sorghum elite lines of the sorghum breeding program of Embrapa Maize and Sorghum Research Center. Mixtures were sown in areas of approximately $1000 \mathrm{~m}^{2}$ in the experimental area of Embrapa Maize and Sorghum Research Center in Sete Lagoas and Embrapa Temperate Climate Research Center in Pelotas. In Cravinhos, samples were collected in both years from the experimental areas of Dow Agrosciences. In each location, the area was subdivided in segments of $100 \mathrm{~m}^{2}$, from which leaves of 5-6 infected plants were collected. From each plant a single spore isolate was obtained totaling 50 isolates per location per year. Infected tissues were placed in paper envelopes and kept at room temperatures until isolation.

For the production of single spore isolates, host tissue of each specimen was surface sterilized for 1 minute at $0,5 \%$ sodium hypochlorite, plated out on oat meal agar (OMA) and incubated under continuous fluorescent light at $25^{\circ} \mathrm{C}$ for $7-8$ days to induce sporulation. Conidia were harvested by flooding plates with sterile distilled water, followed by serial dilution to obtain a conidial suspension at a concentration of 50-100 spores/ 
$\mathrm{ml}$. One $\mathrm{ml}$ of this suspension was transferred to a petri dish containing $2 \%$ water-ágar and incubated at room temperature under continuous fluorescent light for 12 hours for conidial germination. One conidium per leaf was obtained, under the light microscope. Individual germinated spores were outlined on the medium by a wire loop fastened below the low power objective of a microscope. The outlined spore was examined for the presence of other spores and if none was observed, the selected spore was transferred to OMA culture tubes. After development, cultures were flooded with sterile mineral oil for maintenance.

Sorghum genotypes CMSXS112A, CMSXS211A, CMSXS212A, CMSXS215A, CMSXS221A, CMSXS116R, CMSXS181R, CMSXS225R, CMSXS226R, CMSXS227R were used as differentials in this study. These lines were also the components of the genotype mixture utilized for the sampling of isolates. The 10 differentials were planted in a split-plot arrangement using a randomized complete block design, with isolates randomized as whole plots and sorghum genotypes as sub-plots. Due to limitation of space in the greenhouse isolates were inoculated in groups of five. One experiment consisted of the 10 differentials and 5 isolates in two replications. One pot containing 5-6 plants was considered as a replication.

Inoculum was produced by growing monoconidial isolates on OMA for 7-8 days at $25^{\circ} \mathrm{C}$, under continuous fluorescent light to induce sporulation. After incubation, individual plates were flooded with $10 \mathrm{ml}$ sterile distilled water and scrapped with a scalpel to dislodge conidia. The spore suspension was passed through a double layer of cheesecloth to retain fragments of mycelia and culture media. The filtered spore suspension was adjusted to a concentration of $10^{6}$ conidia/ ml. Tween 20 (3 drops/l) was added to each suspension as a wetting agent. Inoculum was applied on the leaf surface of 28 day-old plants with a hand sprayer and plants were incubated for 18 hours in a dew deposition chamber at $100 \%$ relative humidity.

Plants were classified for infection type 12 days after inoculation, based on a 1 to 5 scale, according to the criteria below:

1. Presence of chlorotic flecks;

2. Red spots on the leaf lamina;

3. Necrotic lesions, sometimes elongated, but no acervuli formed;

4. Necrotic lesions formed with acervuli present in the center;

5. Necrotic lesions, sometimes coalescing with abundant sporulation.

Symptoms were separated into two classes of reaction: $\mathrm{R}=$ resistant reaction (including infection types 1,2 , and 3 ) and $\mathrm{S}=$ susceptible reaction (including infection types 4 and 5).

Pathotypes were classified according to Habgood (1970) and Limpert \& Muller (1994). To obtain informations on possible associations of pathogenicity in the populations of $C$. graminicola, association analysis of pathogenicity was performed according to Browder \& Eversmeyer (1977). Isolates were classified, according to their virulence to each possible combination of two lines $a$ and $b$, in one of the four possible categories: $\mathrm{AaAb}$ (avirulent to both lines), $\mathrm{VaAb}$ (virulent to line $\mathrm{a}), \mathrm{AaVb}$ (virulent to line $\mathrm{b}$ ), $\mathrm{VaVb}$ (virulent to lines a and $\mathrm{b}$ ). For each host - pair line combination a pathogenicity association coefficient (PAC) and a virulence association coefficient (VAC) were calculated as follows:

$\mathrm{PAC}=($ No. of isolates $\mathrm{AaAb})+($ No. of isolates $\mathrm{VaVb}$ )/Total No. of isolates in the sample $\mathrm{VAC}=($ No. of isolates $\mathrm{VaVb}) /$ Total No. 
of isolates in the sample.

Population phenotypic diversity was evaluated through the Shannon diversity index (Groth \& Roelfs, 1987), as follows:

$\mathrm{D}=\Sigma \mathrm{p} i \ln (\mathrm{p} i)$ where:

$\mathrm{D}=$ Shannon diversity index

$\mathrm{p} i=$ Frequency of the $i$ th phenotype or

race in the sample.

The effects of virulence frequency and of the association of virulence factors on the diversity of the populations of $C$. graminicola analyzed were determined according to Groth and Roelfs (1987), based on the effects of these factors on the Shannon index. The effect of virulence frequency was calculated based on the assumption that each virulence gene has an equal effect on $\mathrm{D}$, if the virulence frequency of each gene is the same. Maximum diversity occurs in a hypothetical pathogen population that has each virulence at 0,5 frequency. If this is not so, then each added differential line increases the value of D differently, which can be expressed as:

$-\Delta \mathrm{D}=-[(0,5+d i) \ln (0,5+d i)+(0,5-d i) \ln (0,5$

$-d i)]$

where:

$\Delta \mathrm{D}$ is the change in the Shannon index by addition of the $i$ th differential, $d i$ is the departure from the frequency of 0,5 of virulence on the $i$ th differential. If $d i=0$, the equation above was reduced to $-\ln$ $(0,5)$., that is, if there was no departure from the 0,5 frequency, maximum possible diversity would be expressed by the addition of the $i$ th differential. The difference between this maximum increase in $\mathrm{D}$ and the real increase, considering the departure from 0,5 virulence frequency, corresponded to the effect of the degree of polymorphism on the diversity of the population.

The effect of virulence association was calculated based on the property that maximum virulence diversity with the Shannon index, occurs in a pathogen population that has each virulence gene independent of every other, i. e. no epistasis, allelism or linkage disequilibrium (including association due to vegetative propagation of a small number of races). Virulence association was calculated as the difference between the value of $\Delta \mathrm{D}$ and the real Shannon diversity index calculated as $\mathrm{D}=\Sigma \mathrm{p} i \ln (\mathrm{p} i)$.

\section{Results and Discussion}

A total of 75 different virulent phenotypes were identified among the 314 monoconidial isolates. Forty - five pathotypes were identified in each year, from which 16 were common to both years of collections. Sixteen pathotypes made up $68 \%$ of all isolates and only four pathotypes $(22.14,23.14,22.15$, and 22.12) were detected in all years and locations. The most commonly identified pathotype was $22.14(9,55 \%$ of the isolates). This pathotype, which is virulent to CMSXS211, CMSXS212, CMSXS221, CMSXS181, CMSXS225, CMSXS226, was found throughout all areas (Table 1). None of the sorghum differentials was resistant to all races identified in this study.

Virulence frequencies to sorghum lines CMSXS212B, CMSXS215B, CMSXS221B, CMSXS226R, and CMSXS227R were constant throughout years and locations. A higher frequency of isolates with virulence to CMSXS112B was detected in Sete Lagoas in relation to Cravinhos and Pelotas. Some variation from year to year was also observed in relation to sorghum genotypes; a decrease in the frequency of virulence to CMSXS116R was observed in all locations and in relation to CMSXS225R and CMSXS211B in Cravinhos from 1999 to 2000. Low virulence frequency was observed in relation to sorghum lines CMSXS215B and CMSXS227R (Table 2). 
TABLE 1. Predominant virulence phenotypes identified in 314 monoconidial isolates of Colletotrichum graminicola collected in three areas of occurrence of anthracnose in Brazil.

\begin{tabular}{|c|c|c|c|c|c|c|}
\hline \multirow{2}{*}{$\begin{array}{l}\text { Virulence } \\
\text { Pattern }\end{array}$} & \multicolumn{5}{|c|}{ Location $^{1} /$ No. of Isolates } & \multirow{2}{*}{ Total } \\
\hline & $\mathbf{A}$ & B & $\mathbf{C}$ & D & $\mathbf{E}$ & \\
\hline 22.14 & 05 & 11 & 03 & 03 & 08 & 30 \\
\hline 23.12 & 11 & 01 & 15 & 00 & 01 & 28 \\
\hline 23.15 & 15 & 00 & 05 & 01 & 03 & 27 \\
\hline 23.14 & 06 & 03 & 05 & 03 & 07 & 24 \\
\hline 22.15 & 05 & 06 & 05 & 02 & 02 & 20 \\
\hline 22.08 & 00 & 05 & 01 & 02 & 05 & 13 \\
\hline 22.10 & 00 & 02 & 01 & 04 & 03 & 10 \\
\hline 20.08 & 05 & 02 & 00 & 02 & 01 & 10 \\
\hline 20.10 & 02 & 01 & 00 & 06 & 00 & 09 \\
\hline 22.12 & 03 & 03 & 01 & 01 & 01 & 09 \\
\hline 23.30 & 00 & 07 & 01 & 00 & 00 & 08 \\
\hline 23.10 & 05 & 00 & 00 & 01 & 00 & 06 \\
\hline 23.31 & 05 & 01 & 00 & 00 & 00 & 06 \\
\hline 31.12 & 03 & 01 & 00 & 01 & 00 & 05 \\
\hline 00.08 & 01 & 00 & 01 & 02 & 01 & 05 \\
\hline 05.08 & 03 & 00 & 00 & 02 & 00 & 05 \\
\hline
\end{tabular}

1/ A = Sete Lagoas (1999); B = Cravinhos (1999); C = Sete Lagoas (2000); D = Cravinhos (2000); E = Pelotas (2000).

TABLE 2. Virulence frequency to ten sorghum lines in samples collected in three areas of occurrence of anthracnose in Brazil.

\begin{tabular}{lccccc}
\hline \multirow{2}{*}{ Cultivar } & \multicolumn{5}{c}{ Virulence Frequency } \\
\cline { 2 - 6 } & A & B & C & D & E \\
\hline CMSXS112B & 0,65 & 0,37 & 0,78 & 0,27 & 0,25 \\
CMSXS211B & 0,79 & 0,91 & 0,86 & 0,54 & 0,84 \\
CMSXS212B & 0,91 & 0,90 & 0,96 & 0,94 & 0,86 \\
CMSXS215B & 0,07 & 0,10 & 0,00 & 0,08 & 0,07 \\
CMSXS212B & 0,90 & 0,87 & 0,90 & 0,81 & 0,86 \\
CMSXS116R & 0,36 & 0,33 & 0,14 & 0,08 & 0,16 \\
CMSXS181R & 0,61 & 0,61 & 0,31 & 0,62 & 0,64 \\
CMSXS225R & 0,73 & 0,70 & 0,79 & 0,39 & 0,64 \\
CMSXS226R & 0,95 & 0,87 & 1,00 & 0,94 & 1,00 \\
CMSXS227R & 0,07 & 0,01 & 0,08 & 0,00 & 0,00 \\
\hline
\end{tabular}

1/ A = Sete Lagoas (1999); B = Cravinhos (1999); C = Sete Lagoas (2000); D = Cravinhos (2000); E = Pelotas (2000).

Six $\mathrm{A}$ and $\mathrm{R}$ lines combinations were also observed for 11 three-line combinations, identified for which a high PAC and a low VAC formed by the association between two A or B values were found. High PAC and low VAC were lines and one R line (Table 3). Virulence diversity 
TABLE 3. Pathogenicity and virulence associations coefficients of Colletotrichum graminicola in $17 \mathrm{~A}$ and $\mathrm{R}$ line combinations estimated in three locations in 1999 and 2000.

\begin{tabular}{|c|c|c|c|c|c|c|c|c|c|c|}
\hline \multirow{2}{*}{$\begin{array}{l}\text { Line } \\
\text { Combinations }\end{array}$} & \multicolumn{2}{|c|}{ Sete Lagoas ${ }^{2}$} & \multicolumn{2}{|c|}{ Cravinhos $^{2}$} & \multicolumn{2}{|c|}{ Sete Lagoas $^{3}$} & \multicolumn{2}{|c|}{ Cravinhos $^{3}$} & \multicolumn{2}{|c|}{ Pelotas $^{3}$} \\
\hline & PAC & CAV & PAC & CAV & PAC & CAV & PAC & CAV & PAC & CAV \\
\hline $1 \times 4$ & 0,380 & 0,050 & 0,642 & 0,057 & 0,224 & 0,000 & 0,687 & 0,021 & 0,680 & 0,000 \\
\hline $1 \times 10$ & 0,420 & 0,070 & 0,643 & 0,014 & 0,327 & 0,080 & 0,729 & 0,000 & 0,750 & 0,000 \\
\hline $4 \times 6$ & 0,610 & 0,020 & 0,686 & 0,057 & 0,857 & 0,000 & 0,833 & 0,000 & 0,770 & 0,000 \\
\hline $4 \times 10$ & 0,860 & 0,000 & 0,885 & 0,000 & 0,918 & 0,000 & 0,917 & 0,000 & 0,930 & 0,000 \\
\hline $6 \times 10$ & 0,700 & 0,070 & 0,686 & 0,014 & 0,776 & 0,000 & 0,917 & 0,000 & 0,841 & 0,000 \\
\hline$(1 \times 2) \times 6$ & 0,680 & 0,320 & 0,642 & 0,171 & 0,428 & 0,143 & 0,771 & 0,021 & 0,750 & 0,070 \\
\hline$(1 \times 2) \times 10$ & 0,480 & 0,070 & 0,643 & 0,014 & 0,367 & 0,082 & 0,812 & 0,000 & 0,770 & 0,000 \\
\hline$(1 \times 3) \times 10$ & 0,430 & 0,070 & 0,657 & 0,014 & 0,327 & 0,082 & 0,730 & 0,000 & 0,770 & 0,000 \\
\hline$(1 \times 4) \times 6$ & 0,630 & 0,020 & 0,700 & 0,043 & 0,857 & 0000 & 0,920 & 0,000 & 0,840 & 0,000 \\
\hline$(1 \times 4) \times 10$ & 0,880 & 0,000 & 0,923 & 0,000 & 0,918 & 0,000 & 0,980 & 0,000 & 1,000 & 0,000 \\
\hline$(2 \times 4) \times 6$ & 0,620 & 0,020 & 0,686 & 0,057 & 0,677 & 0,090 & 0,857 & 0,000 & 0,850 & 0,000 \\
\hline$(2 \times 4) \times 10$ & 0,871 & 0,000 & 0,885 & 0,000 & 0,918 & 0,000 & 0,940 & 0,000 & 0,950 & 0,000 \\
\hline$(3 \times 4) \times 6$ & 0,610 & 0,020 & 0,628 & 0,060 & 0,857 & 0,000 & 0,850 & 0,000 & 0,840 & 0,000 \\
\hline$(3 \times 4) \times 10$ & 0,860 & 0,000 & 0,885 & 0,000 & 0,918 & 0,000 & 0,940 & 0,000 & 0,930 & 0,000 \\
\hline$(4 X 5) \times 6$ & 0,612 & 0,020 & 0,700 & 0,057 & 0,857 & 0,000 & 0,900 & 0,020 & 0,800 & 0,000 \\
\hline$(4 \times 5) \times 10$ & 0,857 & 0,000 & 0,900 & 0,000 & 0,918 & 0,000 & 0,940 & 0,000 & 0,950 & 0,000 \\
\hline
\end{tabular}

$1 / 1=\operatorname{CMSXS112;} 2=\operatorname{CMSXS211;3}=\operatorname{CMSXS212;} 4=\operatorname{CMSXS215;5}=\operatorname{CMSXS221;6}=\operatorname{CMSXS116} ; 7=$ CMSXS181; $8=$ CMSXS225; $9=$ CMSXS226; $10=$ CMSXS227.

2/ Isolados de 1999. 3/ Isolados de 2000.

TABLE 4. Components of diversity for virulence in populations of Colletotrichum graminicola in three locations in 1999 and 2000.

\begin{tabular}{lcccc}
\hline \multirow{2}{*}{ Location } & \multicolumn{3}{c}{ Shannon diversity index } & \multirow{2}{*}{ Number of races } \\
\cline { 2 - 4 } & Dr & Pd & Pa & \\
\hline Sete Lagoas $^{2}$ & 3,031 & 2,684 & 1,340 & 34 \\
Cravinhos $^{2}$ & 3,102 & 2,576 & 1,247 & 32 \\
Sete Lagoas $^{3}$ & 2,302 & 3,148 & 1,294 & 22 \\
Cravinhos $^{3}$ & 3,076 & 2,826 & 1,118 & 30 \\
Pelotas $^{3}$ & 2,570 & 2,193 & 2,177 & 21 \\
\hline
\end{tabular}

1/ Dr - Observed diversity. Pd - Losses due to deviations from the ideal virulence frequency of 0,5. Pa - Losses due to virulence associations in the pathogen.

2/ Amostras coletadas em 1999.

3/ Amostras coletadas em 2000.

was high in all populations analyzed as indicated by the Shannon index. Losses in the Shannon diversity index were determined primarily by deviations from the ideal virulence frequency of 0,5 as compared to losses determined by virulence association in the pathogen population (Table 4). Losses due to deviations were variable from $50 \%$ in Pelotas to $72 \%$ in Cravinhos. The diversity indexes observed in this paper, confirm the high variability of $C$. graminicola in Brazilian 
conditions. Losses in the Shannon index, in the populations analyzed, were mostly determined by the deviation of the ideal virulence frequency of 0,5 to each sorghum genotypes included in the mixture, which is in agreement with previous results obtained by Casela et al. (2001).

Genetic resistance has been the most reliable and economical method for the control of sorghum anthracnose. This strategy, although apparently simple, is sometimes threatened by the numerous physiological races of the pathogen, that often result in breakdown of resistance. Despite this difficulty it is possible the identification of durable resistance, which requires the screening of sorghum genotypes against multiple races of the pathogen at multiple locations (Pande et al., 1994; Mathur et al., 2003). Lines CMSXS215B, CMSXS116, and CMSXS227R were present in all combinations with high PAC and low VAC, which indicates them as potentially stable sources of resistance to $C$. graminicola. Three-line combinations with high PAC and low VAC suggests the possibility of inclusion of susceptible hybrids in the construction of highly resistant three-cross hybrids, even with the inclusion of susceptible lines in the combination, as indicated by the association involving the highly susceptible lines CMSXS211, CMSXS212, and CMSXS221. Another alternative, is the construction of highly effective combinations that can completely exclude all the virulence diversity present in the pathogen population, by the inclusion of three highly resistant lines. As already demonstrated, pathotype network of C. graminicola in Brazil is not an artifact of sampling of random combinations of virulence in this pathogen population. Many pathotypes may be absent for reasons of general low fitness (Casela et al., 1995;
Casela et al., 2001). Three-way hybrids of sorghum between a single-cross hybrid, involving two different $\mathrm{A}$ and $\mathrm{B}$ lines, with a $\mathrm{R}$ line are already under evaluation as an alternative for stable and durable resistance to this pathogen. Understanding the ability of the pathogen to respond to each of these potentially useful combinations will be a key factor for the success of this strategy.

\section{Conclusions}

Virulence diversity was high in all populations analyzed. Losses in the diversity index were determined primarily by deviations from the ideal virulence frequency of 0,5 as compared to losses determined by virulence association in the pathogen population.

Six two-line and 11 three-line combinations were identified with low virulence association in the pathogen population. Lines CMSXS215B, CMSXS116R, and CMSXS227R, present in all combinations with high PAC and low VAC, were identified as potential sources for stable and durable resistance to C. graminicola.

\section{References}

ALI, M. E. K.; WARREN, H. L.; Physiological Races of Colletotrichum graminicola on sorghum. Plant Disease, St. Paul, v. 71, p. $402-$ 404, 1987.

BROWDER, L. E.; EVERSMEYER, M. G. Pathogenicity associations in Puccinia recondita tritici. Phytopathology, St. Paul, v. 67, p. $766-$ 771, 1977.

CARDWELL, K. F.; HEPPERLY, P. R.; FREDERIKSEN, R. A. Pathotypes of Colletotrichum graminicola and seed transmission of sorghum anthracnose. Plant

Disease, St. Paul, v. 73, p. 255-257, 1989. 
CASELA, C. R.; FERREIRA, A. S. Proposta de um sistema de classificação de raças de Colletotrichum graminicola agente causal da antracnose em sorgo (Sorghum bicolor). Fitopatologia Brasileira, Brasília, v. 12, n. 4, p. 337 - 344, 1987.

CASELA, C. R.; FERREIRA, A. S.; SANTOS, F. G. Associação de virulência de Colletotrichum graminicola à resistência genética em sorgo. Fitopatologia Brasileira, Brasília, v. 23. p. 143 - 146, 1998.

FERREIRA, A. S.; WARREN, H. L. 1982. Resistance of sorghum to Colletotrichum graminicola. Plant Disease, St. Paul, v. 66, p. 773-775, 1982.

GUIMARÃES, F. B.; CASELA, C. R.; SANTOS,
F. G.; FERREIRA, A. S. Controle da antracnose do sorgo através da utilização de mistura de cultivares. Summa Phytopathologica, Jaboticabal, v. 24, p. 131-135, 1998.

GROTH, J. V.; ROELFS, A. P. The concept and measurement of phenotypic diversity in Puccinia graminis on wheat. Phytopathology, St. Paul, v. 77, p. 1395 - 1399, 1987.

HABGOOD, R. M. Designation of physiological races of plant pathogens. Nature, London, v. 227, p. $1268-1269,1970$.

HARRIS, H. B.; JOHNSON, J. B. Sorghum anthracnose symptoms, importance and resistance. In: GRAIN SORGHUM RESEARCH AND UTILIZATION CONFERENCE, 5., 1967, Lubbock. Proceedings... Lubbock: GSPA, 1997. p. $48-52$.

LIMPERT, E.; MULLER, K. Designation of pathotypes of plant pathogens. J. Phytopathology, St. Paul, v. 140, p. 346-358, 1994.

MATHUR, K.; THAKUR. R. P.; NEYA. A.; MARLEY, P. S.; CASELA, C. R.; ROSEWICH, L. U. Sorghum Anthracnose - Problem and Management Strategies. In: GLOBAL 2000: SORGHUM AND PEARL MILLET DISEASES 3., 2000, Guanajuato. Proceedings... Sorghum and Millet International Research. Intsormil, 2003. In press.

PANDE, R. P.; THAKUR, R. P.; KARUNAKAR, R. I.; BANDYOPADHYAY, R; REDDY, B. V. S. Development of screening methods and identification of stable resistance to anthracnose in sorghum. Field Crops Research, Amsterdam, v. 38, p. 157-166, 1998. 